DOI: https://doi.org/10.31933/dijms.v3i1

Received: 3 August 2021, Revised: 24 August 2021, Publish: 28 September 2021

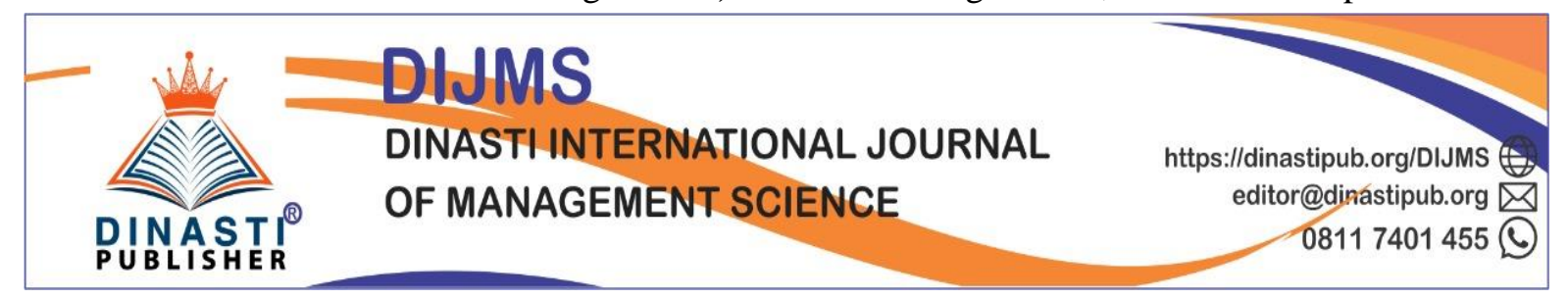

ANALYSIS OF FINANCIAL PERFORMANCE USING ECONOMIC

VALUE ADDED (EVA) AND MARKET VALUE ADDED (MVA)

APPROACH OF STATE-OWNED BANKS (BUMN) LISTED ON INDONESIA STOCK EXCHANGE

\author{
Satria Adhitama1, Muhammad Abdul Muis ${ }^{2}$ \\ Politeknik Keuangan Negara STAN, Tagerang Selatan, Indonesia \\ Politeknik Bisnis dan Pasar Modal, Jakarta, Indonesia
}

Corresponding Author: Satria Adhitama

\begin{abstract}
This study aims to analyze financial performance using Economic Value Added (EVA) and Market Value Added (MVA) approaches of state owned Banks (BUMN) listed on Indonesia Stock Exchange. The research methodology used qualitative descriptive research. The objects of this study are the state owned Banks (BUMN) listed on Indonesia Stock Exchange 2016-2018. The data collection techniques used are secondary data and panel data. The analysis techniques used are by calculating Economic Value Added (EVA) and Market Value Added (MVA). The results of this study indicate that the financial performance of the state owned Banks (BUMN) listed on Indonesia Stock Exchange 2016-2018 in terms of Economic Value Added (EVA) has good financial performance because the Economic Value Added value always more than zero (EVA>0). In terms of Market Value Added (MVA), in 2016 Bank BNI had negative MVA value (MVA <0) then in 2017 and 2018.BNI Bank had positive MVA value (MVA>0). BRI and Mandiri Bank had positive MVA value (MVA $>0$ ) in 2016-2018. BTN Bank in 2016-2018 had negative MVA (MVA <0).
\end{abstract}

Keywords: Bank, BUMN, EVA, Financial Performanc, MVA

\title{
INTRODUCTION
}

\section{Research Background}

The current economic conditions, companies must be able to manage activities effectively based on the objectives to be achieved. The main objective of a company is to maximize profit by increasing demand and minimizing company costs or expenses. The purpose of go public companies which their shares are traded on the stock market is to maximize the value of shares because the value of existing shares is a reflection of the wealth of shareholders or investors. Thus, for companies whose ownership is owned by the public, the value of the company is associated with the shares outstanding in the market. (Suripto, 2015: 1)

According to Hery (2016: 2) financial statements are the result of the accounting process that can be used as a tool to communicate financial data or company activities to interested parties. Performance is a measure of whether a decision taken or a strategy implemented is good or bad for the company. Performance measurement is the result or level of success of a 
person as a whole during a certain period in carrying out tasks compared to various possibilities, such as work standards, targets or targets or performance that have been determined in advance and have been agreed upon. (Mulyadi, 2011: 337).

According to Young and O'Byrne (2001) in Sunardi (2018), Economic Value Added (EVA) is a measurement of financial performance by calculating the difference between the company's return on capital and the cost of capital. EVA is a measurement used to monitor the overall value creation in a business. There are several movers that need to be managed, but EVA is only a measurement that can describe success. A single measurement is needed as the last reference of a performance that can help managers to balance conflicting goals. (Suripto, 2015: 73).

MVA is the difference between the market value of the company's shares and the amount of equity investors have invested in. MVA is the resultcumulative of the company's performance generated by the various investments that have been made or will be made. Thus MVA is a reflection of investors' expectations of the total value they expect from the company to create future value with less total capital invested in the company. (Keown et al 2010: 35).

Bank Negara Indonesia (Persero), Tbk was initially established in Indonesia as the central bank under the name "Bank Negara Indonesia" based on Government Regulation in Lieu of Law no. 2 of 1946 dated July 5, 1946. BNI was the first state-owned bank (State-Owned Enterprise) to become a public company after listing its shares on the Jakarta Stock Exchange and Surabaya Stock Exchange in 1996to serve its customers(bni.co.id). PT Bank Rakyat Indonesia (Persero), Tbk is one of the largest stateowned banks in Indonesia. Bank BRI was established on December 16, 1895, which later became the birthday of BRI. In the period after the independence of the Republic of Indonesia, based on Government Regulation no. 1 of 1946 Article 1 states that BRI is the first Government Bank in the Republic of Indonesia(bri.co.id).

Bank Tabungan Negara (Persero), Tbk was established on February 9, 1950 under the name Bank Tabungan Pos. In 1992 the status of BTN Bank became PT Bank Tabungan Negara (Persero) due to its success in the housing business through mortgage facilities. The success of BTN Bank in the mortgage business has also upgraded BTN Bank status as a conventional bank to a foreign exchange bank in 1994. On December 8, 2009, BTN Bank obtained a statement of effectiveness from Bapepam-LK to conduct a public offering of shares to the public. The shares were listed on the Indonesia Stock Exchange on December 17, 2009 (btn.co.id). Mandiri Bank was established on October 2, 1998, as part of the banking restructuring program implemented by the Indonesian government. In July 1999, four state banks, namely Bank Bumi Daya, Bank Dagang Negara, The Export Import Bank of Indonesia, and the Indonesian Development Bank were merged into Mandiri Bank. On July 14, 2003, Mandiri Bank finally listed its initial shares with the stock code BMRI on the Surabaya Stock Exchange (bankmandiri.co.id).

Formulation of the problem

a. How was the financial performance of PT Bank Negara Indonesia (Persero), Tbk, PT Bank Rakyat Indonesia (Persero), Tbk, PT Bank Tabungan Negara (Persero), Tbk, and PT Bank Mandiri (Persero), Tbk measured using the Economic Value Added (EVA) approach in 2016-2018?

b. How was the financial performance of PT Bank Negara Indonesia (Persero), Tbk, PT Bank Rakyat Indonesia (Persero), Tbk, PT Bank Tabungan Negara (Persero), Tbk, and PT Bank 
Mandiri (Persero), Tbk measured using the Market Value Added (MVA) approach in 20162018 ?

c. How was the financial performance of PT Bank Negara Indonesia (Persero), Tbk, PT Bank Rakyat Indonesia (Persero), Tbk, PT Bank Tabungan Negara (Persero), Tbk, and PT Bank Mandiri (Persero), Tbk measured using the Economic Value Added (EVA) and Market Value Added (MVA) approaches in 2016-2018?

\section{LITERATURE REVIEW}

\section{Fundamentals of Management}

According to Siswanto (2011: 2), management is the art and science of planning, organizing, directing, motivating, and controlling people and work mechanisms to achieve goals. According to Sarinah and Mardalena (2017: 7-8), the management process is a series of activities that must be carried out by a manager in an organization.

\section{Financial Management}

According to Rokhmawati (2016: 2) financial management can be interpreted as part of microeconomics which studies companies in relation to the function of obtaining funds and investment functions, in order to increase the value and wealth of company owners. The tasks of financial management include planning where business financing will be obtained, and how the capital that has been obtained is allocated appropriately in the business activities carried out. (Sarinah and Mardalena, 2017: 9).

\section{Capital Market}

Capital market is a meeting between parties who have excess funds and those who need funds by trading securities. Thus, the capital market can also be interpreted as a market for trading securities which generally have a lifespan of more than one year, such as stocks, bonds, and mutual funds. (Tandelilin, 2017: 25).

\section{Financial statements}

Financial statements are the result of the accounting process that can be used as a tool to communicate financial data or company activities to interested parties. In other words, this financial report serves as an information tool that connects the company with interested parties, which shows the company's financial health condition and company performance. (Hery, 2016: 2)

\section{Financial performance}

Performance measurement as the success of personnel, teams, or organizational units in realizing predetermined strategic goals with the expected behavior. In other words, it can be concluded that performance is a measure of whether a decision taken or a strategy implemented is good or bad for the company. (Mulyadi, 2011: 337).

\section{Economic Value Added (EVA)}

Economic Value Added (EVA) is a measurement used to monitor overall value creation in a business. EVA is not a strategy, but an outcome measurement. There are several movers that need to be managed, but Economic Value Added is only a measure that can describe success. A single measure is needed as the last reference of a performance that can help managers to balance conflicting goals. (Suripto, 2015: 73).

According to Keown, et al (2010: 44) EVA is the difference between net operating profit after tax (NOPAT) and capital expense for the period (that is, the product of the company's cost of capital and capital invested at the beginning of the period). Capital expense is the capital invested by the company at the beginning of the period multiplied by the 
company's weighted average cost of capital. This value of the company's net operating profit after tax (NOPAT) to estimate EVA. EVA for years is defined as follows:

$$
\mathrm{EVA}=\text { NOPAT }- \text { Capital charges }
$$

\section{Market Value Added (MVA)}

Market Value Added (MVA) is the difference in market value between the company and its invested capital. Market Value Added (MVA) was invented by Stern Stewart and Company to measure how much wealth a company has created for a given time. MVA can be calculated as follows:

$$
\text { MVA = Firm Value }- \text { Invested Capital }
$$

What is meant by firm value is the market value of the company's debt and equity. The company's invested capital is the sum of all the funds that have been invested in it. (Keown et al 2010: 35). MVA is a reflection of investors' expectations of the total value they expect from the company to create future value with less total capital invested in the company. (Keown, et al 2010: 43).

\section{Bank}

Banks are financial institutions that accept deposits and provide loans. The term bank includes companies, such as commercial banks, savings and loan associations, multi-deposit banks, and credit unions. (Mishkin, 2017: 6). Banks are important financial institutions in the economy of a country. The Bank regulates the payment system and implements government policies in the financial sector. (Feryanto, 2019: 26)

\section{RESEARCH METHOD}

The type of data used in conducting this research is panel data (Time Series and Cross Section) for the period 2016 to 2018. The source of the data used comes from secondary data in the form of company financial reports that have been published and issued by the Indonesia Stock Exchange during the period from 2016 to 2018. The data collection method used is purposive sampling, which is a type of non-random sample selection whose information is obtained using certain considerations or criteria.

The instruments used in this study are data which include Economic Value Added (EVA) and Market Value Added (MVA) from state-owned banking companies in Indonesia during the period 2016 to 2018. Furthermore, the data is first processed in the form of statistical data table using Microsoft Office Excel 2010 program and then the statistical data table is analyzed to see a comparison of the financial performance of the company by using Economic Value Added (EVA) and Market Value Added (MVA). The data analysis technique used in this study is descriptive analysis by calculating financial ratios which are indicators in the assessment of financial performance using the Economic Value Added (EVA) and Market Value Added (MVA) approaches.

\section{FINDING AND DISCUSSION}

Economic Value Added (EVA)

Table 1. EVA of BNI Bank

\begin{tabular}{|l|c|c|c|}
\hline \multicolumn{1}{|c|}{ Information } & 2016 & 2017 & 2018 \\
\hline NOPAT & $21,020,888$ & $25,215,014$ & $27,840,536$ \\
\hline WACC & $5.08 \%$ & $6.73 \%$ & $0.31 \%$ \\
\cline { 3 - 4 } & &
\end{tabular}




\begin{tabular}{|l|c|c|c|}
\cline { 2 - 4 } Invested Capital & $119,501,970$ & $134,963,299$ & $144,519,020$ \\
\hline Capital Charges & $6,068,315$ & $9,084,760$ & 450,309 \\
\hline EVA & $14,952,573$ & $16,130,253$ & $27,390,226$ \\
\hline
\end{tabular}

Source: Data processed by the author, 2020

Based on the table above, the EVA value achieved by Bank BNI for 3 years has increased. The highest EVA value of BNI Bank occurred in 2018 which was 27,390,226. The lowest EVA value of Bank BNI occurred in 2016 which was 14,952,573.

Table 2 EVA of BRI Bank

\begin{tabular}{|c|c|c|c|}
\hline Information & 2016 & 2017 & 2018 \\
\hline NOPAT & $46,484,878$ & $50,261,455$ & $56,123,342$ \\
\hline WACC & $5.16 \%$ & $6.62 \%$ & $0.82 \%$ \\
\hline Invested Capital & 206.275 .179 & $226,056,324$ & 254.111212 \\
\hline Capital Charges & $10,644,602$ & $14,963,685$ & 2.072 .024 \\
\hline EVA & $35,840,276$ & $35,297,769$ & $54,051,317$ \\
\hline
\end{tabular}

Source: Data processed by the author, 2020

Based on the table above, the value of EVA achieved by BRI Bank for 3 years has fluctuated. The highest EVA value of Bank BRI occurred in 2018 which was 54,051,317. The lowest EVA value of BRI Bank occurred in 2017 which was 35,297,769, this result showed a decrease from 2016 which was 35,840,276.

Table 3. EVA of BTN Bank

\begin{tabular}{|l|c|c|c|}
\hline \multicolumn{1}{|c|}{ Information } & 2016 & 2017 & 2018 \\
\hline NOPAT & $9,677,403$ & $11,456,003$ & $12,734,132$ \\
\hline WACC & $5.92 \%$ & $3.30 \%$ & $2.20 \%$ \\
\hline Invested Capital & $42,049,180$ & $53,134,265$ & $62,984,220$ \\
\hline Capital Charges & $2,488,446$ & $1,753,649$ & $1,383,470$ \\
\hline EVA & $7,188,956$ & $9,702,354$ & $11,350,663$ \\
\hline
\end{tabular}

Source: Data processed by the author, 2020

Based on the table above, the value of EVA achieved by BTN Bank for 3 years has increased. The highest EVA value of BTN Bank occurred in 2018 which was 11,350,663. The lowest EVA value of BTN Bank occurred in 2016 which was 7,188,956.

Table 4. EVA of Mandiri Bank

\begin{tabular}{|l|c|c|c|}
\hline \multicolumn{1}{|c|}{ Information } & 2016 & 2017 & 2018 \\
\hline NOPAT & $30,275,054$ & $36,840,479$ & $40,529,771$ \\
\hline WACC & $5.56 \%$ & $4.45 \%$ & $1.07 \%$ \\
\hline Invested Capital & $188,698,632$ & 211.865 .566 & $241,891,501$ \\
\hline Capital Charges & $10,498,017$ & $9,428,102$ & $2,583,622$ \\
\hline EVA & $19,777,038$ & $27,412,378$ & $37,946,149$ \\
\hline
\end{tabular}

Source: Data processed by the author, 2020

Based on the results of the calculation of the EVA value above, it can be seen that the value of Economic Value Added at Mandiri Bank in the last three years has increased. In 2016 Mandiri Bank had an EVA of 19,777,038. In 2017 Mandiri Bank had an EVA of 27,412,378. In 2018 Bank Mandiri had an EVA of 37,946,149. 


\section{Calculating Market Value Added}

Table 5. MVA of BNI Bank

\begin{tabular}{|l|r|r|r|}
\hline \multicolumn{1}{|c|}{ Information } & \multicolumn{1}{c|}{2016} & \multicolumn{1}{c|}{2018} \\
\hline $\begin{array}{l}\text { The value of the } \\
\text { company }\end{array}$ & $103,033,827$ & 184.621 .699 & 164.108 .177 \\
\hline Invested Capital & $119,501,970$ & $134,963,299$ & $144,519,020$ \\
\hline MVA & $-16,468,143$ & $49,658,400$ & $19,589,157$ \\
\hline
\end{tabular}

Source: Data processed by the author, 2020

In 2016 the MVA value of BNI Bank reached -16,468,143, in 2017 it reached $49,658,400$ so in 2018 the added value of BNI Bank reached 19,589,157. The increase in MVA value is due to a tendency to increase the value of the share price per share. Where in 2016 the share price of BNI Bank reached 5,525 per share and in 2018 it increased to 8,800 per share.

Table 6. MVA of BRI Bank

\begin{tabular}{|l|r|r|r|}
\hline \multicolumn{1}{|c|}{ Information } & \multicolumn{1}{c|}{2016} & \multicolumn{1}{c|}{2017} & 2018 \\
\hline $\begin{array}{l}\text { The value of the } \\
\text { company }\end{array}$ & $288.012,466$ & $448,978,748$ & 451.445665 \\
\hline Invested Capital & 206.275 .179 & $226,056,324$ & 254.111212 \\
\hline MVA & $81,737,287$ & $222,922,424$ & 197.334453 \\
\hline
\end{tabular}

Source: Data processed by the author, 2020

BRI Bank also shows a fluctuating MVA value. MVA from BRI Bank in 2016 reached $81,737,287$, in 2017 it reached 222,922,424 and on 2018 increased to 197.334453.

Table 7. MVA of BTN Bank

\begin{tabular}{|l|c|r|r|}
\hline \multicolumn{1}{|c|}{ Information } & 2016 & 2017 & \multicolumn{1}{c|}{2018} \\
\hline $\begin{array}{l}\text { The value of the } \\
\text { company }\end{array}$ & $18,426,600$ & $37,806,300$ & $26,898,600$ \\
\hline Invested Capital & $42,049,180$ & $53,134,265$ & $62,984,220$ \\
\hline MVA & $-23.622,580$ & $-15,327,965$ & $-36,085,620$ \\
\hline
\end{tabular}

Source: Data processed by the author, 2020

The table above shows that the MVA of BTN Bank in 2016-2018 has a negative value. In 2016 the MVA value of BTN Bank reached -23.622,580, in 2017 it reached -15,327,965 in 2018 the added value of BTN Bank reached -36,085,620.

Table 8. MVA of Mandiri Bank

\begin{tabular}{|c|c|c|c|}
\hline Information & 2016 & 2017 & 2018 \\
\hline $\begin{array}{c}\text { The value of the } \\
\text { company }\end{array}$ & $270,083.333$ & 373333333 & $344,166,667$ \\
\hline Invested Capital & $188,698,632$ & 211.865 .566 & $241,891,501$ \\
\hline MVA & $81,384,701$ & $161,467,767$ & 102.275 .166 \\
\hline
\end{tabular}

Source: Data processed by the author, 2020

Meanwhile, the MVA value of Mandiri Bank tends to fluctuate. In 2016 it reached 81,384,701, in 2017 it reached 161,467,767 and in 2018 it reached 102,275,166.

\section{CONCLUSIONS AND SUGGESTIONS}

\section{Conclusion}

a. The financial performance of BUMN Banks based on Economic Value Added in 2016 - 2018 shows that BUMN Banks listed on the Indonesia Stock Exchange have good financial performance because the Economic Value Added value is always more than 
zero $(\mathrm{EVA}>0)$. A positive EVA value indicates that the bank has been able to generate added value to investors from an investment that has been made. EVA is positive, because net operating profit after tax (NOPAT) received by the company is able to finance all expenses or costs incurred on the company's capital so that the EVA value obtained becomes positive.

b. Meanwhile, by using Market Value Added in 2016, BNI Bank had a negative MVA value (MVA < 0) then in 2017 and 2018 BNI Bank had a positive MVA value (MVA $>0$ ). BRI Bank has a positive MVA value (MVA > 0) in 2016-2018. BTN Bank in 2016-2018 had a negative MVA value (MVA < 0). Mandiri Bank has a positive MVA value (MVA > 0) in 2016-2018. A negative MVA (MVA < 0) means the company has poor financial performance. A positive MVA means that the company is able to show market performance that continues to improve and provides high returns for shareholders.

\section{Suggestion}

a. The results of this study are expected to be an additional evaluation material for each bank, so that they can maintain and improve their performance to be better in the next period.

b. For investors, this research can be used as a reference to determine the direction of investment to be made.

c. For the authors of this study, it provides additional insight and knowledge regarding the analysis of financial performance in the banking sector.

d. For further researchers, it is recommended to expand the scope of research by adding research variables, and more samples taken so that the results can be more representative for the entire banking sector.

\section{BIBLIOGRAPHY}

Darmadji, T., \& Fakhruddin, H. M. (2001). Pasar Modal di Indonesia: Pendekatan Tanya Jawab. Jakarta: Penerbit Salemba Empat.

Dewi, G. A. K. R. S. (2018). Investasi dan pasar modal Indonesia. Jakarta: Rajawali Pers.

Firdausi, M. R., Rahadian, D., \& Dewi, A. S. (2017). Analisis Kinerja Keuangan Dengan Menggunakan Metode Economic Value Added (EVA), Financial Value Added (FVA) dan Market Value Added (MVA) Studi Kasus Pada Operator Telekomunikasi yang Terdaftar di BEI Periode 2008-2015. eProceedings of Management, 4(2).

Feryanto, A. (2019). Uang dan Bank. Klaten: Cempaka Putih.

Hery. 2016. Analisis Laporan Keuangan. Jakarta: PT Gramedia Widiasarana Indonesia.

Hery. 2016. Financial Ratio For Business. Jakarta: PT. Grasindo.

Husnan, Suad. (2015). Dasar-Dasar Teori Portofolio dan Analisis Sekuritas. (Edisi 5). Yogyakarta : UPPN STIM YKPN

Keown, A. J., Martin, J. D., Petty, J. W., \& Scoot, D. F. J. (2010). Manajemen Keuangan : Prinsip dan Penerapan Jilid 2. Jakarta: Indeks.

Mishkin, F. S. (2008). Ekonomi Uang, Perbankan, dan Pasar Keuangan. Jakarta: Salemba Empat.

Mulyadi. (2011). Sistem pengendalian Manajemen. Penerbit Salemba Empat. Jakarta.

Purnami, L. P. A., Yudiaatmaja, F., Yulianthini, N. N., \& SE, M. (2016). Kinerja Keuangan Menggunakan Pendekatan Economic Value Added (EVA) dan Market Value Added (MVA) Pada Bank BUMN. Jurnal Manajemen Indonesia, 4(1). 
Riawati, I., Yuliari, K., \& Joewarni, D. (2018). Analisis Kinerja Keuangan Perusahaan Dengan Menggunakan Metode Economic Value Added (EVA) Dan Market Value Added (MVA) Pada Perusahaan Rokok Yang Terdaftar Di BEI Tahun 2012-2016. JIMEK: Jurnal Ilmiah Mahasiswa Ekonomi, 1(1).

Rokhmawati, Andewi. (2016). Manajemen Keuangan. Yogyakarta: Penerbit Deepublish (Grup Penerbitan CV BUDI UTAMA)

Sarinah. dan Mardalena. (2017). Pengantar Manajemen. Yogyakarta: Penerbit Deepublish (Grup Penerbitan CV BUDI UTAMA).

Siswanto. (2015). Pengantar Manajemen. Jakarta: Penerbit PT Bumi Aksara.

Sunardi, Nardi. (2018). " Analisis Economic Value Added (EVA), Financial Value Added (FVA), Dan Market Value Added (MVA) Dengan Time Series Approach Sebagai Alat Penilai Kinerja Keuangan Studi Pada Industri Konstruksi (BUMN) di Indonesia Yang Listing Di BEI Tahun 2013-2017. Jurnal Sekuritas: Vol.2, No. 1, September 2018. ISSN 2581-2777

Suripto, S. (2015). Manajemen Keuangan: Strategi Penciptaan Nilai Perusahaan Melalui Pendekatan Economic Value Added. Edisi Ke-1. Bandung: Alfabeta.

Tandelilin, Eduardus. (2017). Pasar Modal: Manajemen Portofolio dan Investasi. Yogyakarta: Kanisius.

Wijaya, David. (2017). Manajemen Keuangan Konsep dan Penerapannya. Jakarta: PT Grasindo Jakarta. 